\title{
Meta-analysis of segmentectomy versus wedge resection in stage IA non-small-cell lung cancer
}

This article was published in the following Dove Press journal: OncoTargets and Therapy

\author{
Wenfei Xue \\ Guochen Duan \\ Xiaopeng Zhang \\ Hua Zhang \\ Qintao Zhao \\ Zhifei Xin
}

Department of Thoracic Surgery, Hebei Province General Hospital, Shijiazhuang, China
Correspondence: Wenfei Xue Department of Thoracic Surgery, Hebei Province General Hospital, No 348, Heping Road West, Xinhua District, Shijiazhuang 050000, China

Tel +86 I52 32I3 8500

Fax +86 I5 23238500

Email946451310@qq.com
Background: Although limited resection was once considered the surgical treatment for patients with Phase IA non-small-cell lung cancer (NSCLC), there has been an ongoing controversial surgical indication for wedge resection and segmentectomy in recent years. The objective of this study was to compare overall survival (OS) and disease-free survival (DFS) of segmentectomy and wedge resection for early stage NSCLC, using a meta-analysis.

Methods: Systematic research was conducted using four online databases to search for studies published before 2017. The DFS and OS for early stage NSCLC after segmentectomy and wedge resection were compared. The studies were selected according to rigorous predefined inclusion criteria, and meta-analyzed using the $\log$ (hazard ratio; $\ln [\mathrm{HR}]$ ) and its standard error (SE) calculations.

Results: Included in this meta-analysis were nine studies, published from 2006 to 2017, with a total of 7,272 patients. Survival outcome of segmentectomy was comparable to wedge resections for stage IA lung cancer because of OS (similar hazard ratio [HR]: 0.93, 95\% confidence interval $[\mathrm{CI}]$ : $0.83-1.05, P=0.26$ ) and DFS (similar HR: 0.81, 95\% CI: $0.60-1.09, P=0.17$ ). Nevertheless, for stage IA NSCLC with tumor size $\leq 2 \mathrm{~cm}$, segmentectomy was superior to wedge resection (combined HR: $0.82,95 \% \mathrm{CI}$ : $0.70-0.97, P=0.02$ ). However, there were no significant differences in OS rates, 1.07 (95\% CI: $0.78-1.46, P=0.68$ ), between segmentectomy and wedge resection for IA NSCLC with a tumor size of $\leq 1 \mathrm{~cm}$.

Conclusion: This study concluded that segmentectomy could achieve better OS than wedge resection for stage IA NSCLC with a tumor size of $\leq 2 \mathrm{~cm}$. However, surgeons could conduct segmentectomy and wedge resection for NSCLC $\leq 1 \mathrm{~cm}$ according to patient profile and the location of tumor. These results should be confirmed by further randomized clinical trials.

Keywords: segmentectomy, wedge resection, IA NSCLC, meta-analysis

\section{Introduction}

With the wide use of low-dose helical computed tomography (LDCT) and highresolution computed tomography (HRCT) screening in lung cancer, the number of patients with early stage lung cancer has been found to be increasing. ${ }^{1}$ The randomized trial by the Lung Cancer Study Group demonstrated that lobectomy was the standard surgical procedure for stage I non-small-cell lung cancer (NSCLC). ${ }^{2}$ In recent years, many studies indicated similar survival with sublobar resection and lobectomy for stage IA NSCLC. ${ }^{3-9}$ Compared with those who underwent traditional lobectomy, patients who underwent sublobectomy had less lung tissue resected and more lung function preserved. The limited resection surgical approaches included wedge resection and segmentectomy. However, a few studies compared the effect between two types of limited resections; ${ }^{10,11}$ there was no effective evidence regarding 
the selections between segmentectomy and wedge resections for early stage NSCLC. Hence, the controversial problem for many surgeons was how to make a decision between anatomic segmentectomy and extended non-anatomic wedge resection for stage IA NSCLC. This meta-analysis study aimed to compare the outcomes of overall survival (OS) and disease-free survival (DFS) for patients with stage IA NSCLC who underwent either wedge resection or segmentectomy. In addition, subgroup analysis including stage IA NSCLC, tumor size $\leq 2 \mathrm{~cm}$ and $\leq 1 \mathrm{~cm}$ and ground glass opacity (GGO) was performed.

\section{Methods}

\section{Literature search strategy}

A systematic search was performed, using Ovid, PubMed, Embase and Cochrane library databases for studies published before 2017, with the strategy of (limited resection [Title/Abstract]) OR (sublobar resection [Title/Abstract]) OR (segmentectomy [Title/Abstract]) OR (wedge resection [Title/Abstract]) AND (lung cancer [Title/Abstract] OR pulmonary [Title/Abstract]) AND (cancer [Title/Abstract]) OR (carcinoma [Title/Abstract]). Potentially eligible articles were identified from citations of all retrieved articles.

\section{Selection criteria}

The eligible studies were evaluated by two authors based on the inclusion criteria as follows: 1) early stage NSCLC patients including those with stage IA, tumor size $\leq 1 \mathrm{~cm}$ and GGO; 2) sublobar resection or limited resection including wedge resection and segmentectomy; 3) outcome of studies comparing DFS and OS between segmentectomy and wedge resection and 4) when studies were from the same institution and the same period, the most informative study was selected. Letters to editors, case reports, non-English studies and reviews were excluded.

\section{Statistical analyses}

Combing the results of OS and DFS, meta-analysis was performed through hazard ratio (HR) and associated 95\% confidence interval (CI) for each study. The data of HR and standard error (SE) of the selected studies, which were not provided, were extracted from the primary survival curve using the techniques described by Parmar et $\mathrm{al}^{12}$ and Tierney et al. ${ }^{13}$ Two researchers independently calculated the data and read the Kaplan-Meier curves using Engauge Digitizer version 4.1 software. All statistical analyses were summarized using Review Manager version 5.3.0. Statistical heterogeneity was estimated by Higgins $I^{2}$, which represented the total variation percentage among the studies. A fixedeffect model (Mantel-Haenszel method) was used to pool homogeneous studies. If the $I^{2}$ statistic was less than $50 \%$, the random-effect model (DerSimonian-Laird) was used. Begg's funnel plot and Egger's test ${ }^{14}$ were used to assess the publication bias.

\section{Results}

A total of 1,534 studies were obtained from the electronic databases. According to the selection criteria, papers were extracted from the databases as shown in Figure 1. There were finally nine articles published from 2006 to 2017 for this meta-analysis including 1,920 patients who underwent segmentectomy and 5,352 patients who underwent wedge resection. There were one prospective study and eight retrospective studies. The characteristics of the included studies are listed in Tables 1 and 2.

\section{Stage IA NSCLC}

There were 1,735 patients who underwent segmentectomy and 5,154 patients who underwent wedge resection for stage IA NSCLC. As there was no significant heterogeneity $(P=0.18)$, the fixed-effect model was used for analysis. The combined HR of OS was 0.93 (95\% CI: 0.83-1.05, $P=0.26$; Figure 2). The DFS data were detected from six eligible articles including 577 patients who underwent segmentectomy and 478 patients who underwent wedge resection. Pooled HR of DFS was 0.81 (95\% CI: 0.60-1.09, $P=0.17$; Figure 3 ) using fixed-effect model for no heterogeneity. For tumor size $\leq 2 \mathrm{~cm}$, there were six eligible papers. Combining the HR of OS using the fixed-effect model, the result was 0.82 (95\% CI: $0.70-0.97, P=0.02$; Figure 4). It showed that segmentectomy was superior to wedge resection for tumor size $\leq 2 \mathrm{~cm}$. Two studies provided the data for patients in early stage NSCLC (tumor size $\leq 1 \mathrm{~cm})$. As the study of Dai et $\mathrm{al}^{24}$ used the same database as the research of Zhang et al, ${ }^{23}$ Dai et al's study could not be included. However, it provided the research about the tumor size $\leq 1 \mathrm{~cm}$. The pooled HR of OS was 1.07 (95\% CI: 0.78-1.46, $P=0.68$; Figure 5). There were two studies about the GGO NSCLC. Analyzing the data of these studies, OS of combining HR was 1.79 (95\% CI: $0.33-9.55, P=0.50$; Figure 6$)$. DFS of combining HR was 1.68 (95\% CI: $0.20-13.94, P=0.63$; Figure 7). There was no significant difference between segmentectomy and wedge resection for GGO NSCLC. 


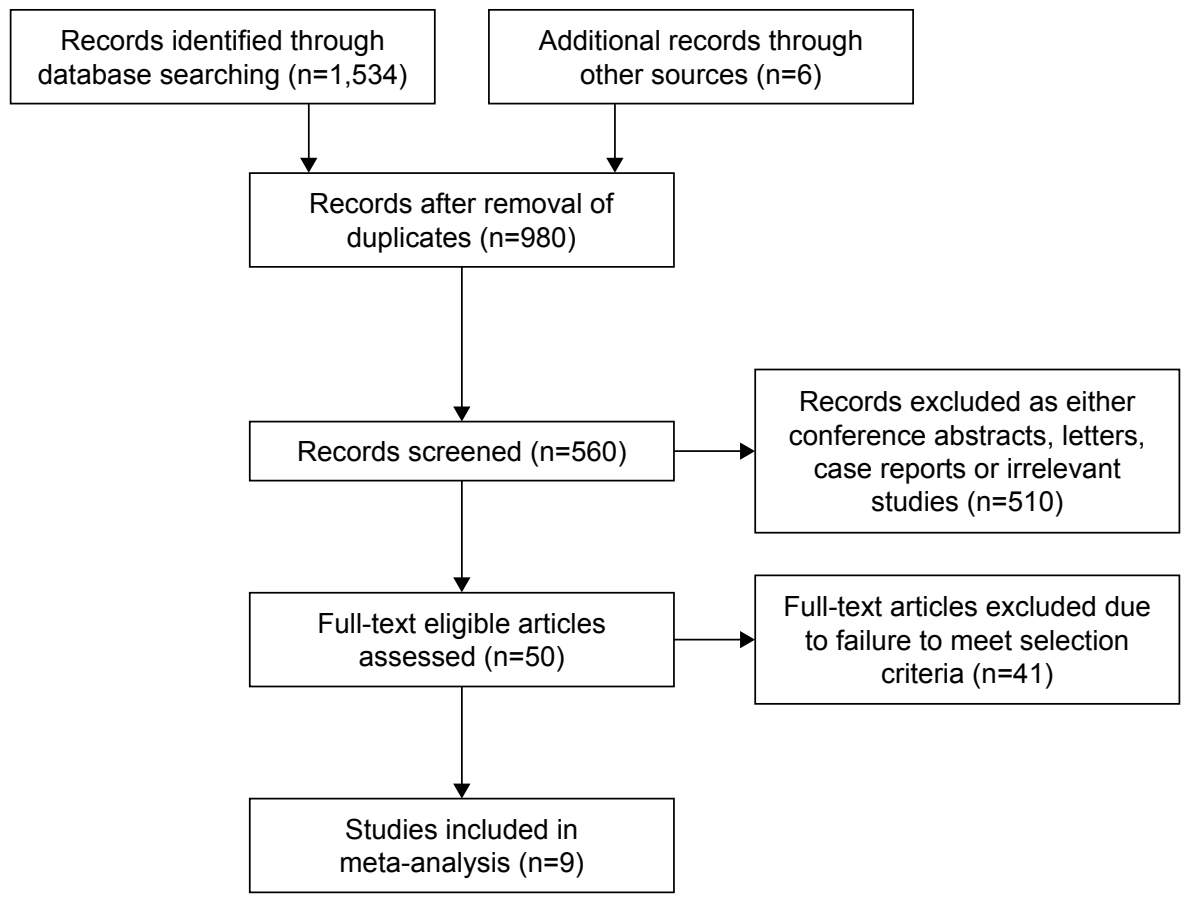

Figure I Search strategy.

Table I Characteristics of the included studies

\begin{tabular}{|c|c|c|c|c|c|c|c|}
\hline Study & Year & Institution & $\begin{array}{l}\text { Study } \\
\text { period }\end{array}$ & $\begin{array}{l}\text { Segmentectomy } \\
\text { (n) }\end{array}$ & $\begin{array}{l}\text { Wedge } \\
\text { resection (n) }\end{array}$ & $\begin{array}{l}\text { Reasons for sublobar } \\
\text { approach }\end{array}$ & $\begin{array}{l}\text { Tumor } \\
\text { size }(\mathrm{cm})\end{array}$ \\
\hline $\begin{array}{l}\text { Okada } \\
\text { et } \mathrm{al}^{7}\end{array}$ & 2006 & $\begin{array}{l}\text { Department of Thoracic } \\
\text { Surgery, Hyogo Medical } \\
\text { Center for Adults, Akashi } \\
\text { City, Hyogo, Japan }\end{array}$ & $|992-200|$ & 214 & 30 & Intentional & 2.0 \\
\hline Sugi et $\mathrm{al}^{8}$ & 2010 & $\begin{array}{l}\text { National Hospital } \\
\text { Organization, Yamaguchi- } \\
\text { Ube Medical Center, } \\
\text { Japan }\end{array}$ & $200 \mathrm{I}-2004$ & 33 & 15 & Intentional & 2.0 \\
\hline $\begin{array}{l}\text { Hamatake } \\
\text { et al }{ }^{17}\end{array}$ & 2012 & $\begin{array}{l}\text { Breast and Paediatric } \\
\text { Surgery, Fukuoka } \\
\text { University School of } \\
\text { Medicine, Fukuoka, Japan }\end{array}$ & |995-20| & 34 & 32 & Intentional & 1.0 \\
\hline $\begin{array}{l}\text { Sienel } \\
\text { et } \mathrm{al}^{18}\end{array}$ & 2008 & $\begin{array}{l}\text { Department of Thoracic } \\
\text { Surgery, Albert-Ludwigs- } \\
\text { University Freiburg, } \\
\text { Freiburg, Germany }\end{array}$ & $1987-2003$ & 56 & 31 & $\begin{array}{l}\text { Unintentional for patients } \\
\text { with cardiopulmonary } \\
\text { impairment }\end{array}$ & 3.0 \\
\hline $\begin{array}{l}\text { Sienel } \\
\text { et } \mathrm{al}^{18}\end{array}$ & 2008 & $\begin{array}{l}\text { Department of Thoracic } \\
\text { Surgery, Albert-Ludwigs- } \\
\text { University Freiburg, } \\
\text { Freiburg, Germany }\end{array}$ & $1987-2003$ & 35 & 25 & $\begin{array}{l}\text { Unintentional for patients } \\
\text { with cardiopulmonary } \\
\text { impairment }\end{array}$ & 2.0 \\
\hline $\begin{array}{l}\text { Yamato } \\
\text { et al }{ }^{19}\end{array}$ & 2008 & $\begin{array}{l}\text { Chest Surgery, Niigata } \\
\text { Cancer Center Hospital, } \\
\text { Niigata, Japan }\end{array}$ & $|99|-2004$ & 153 & 93 & $\begin{array}{l}\text { Unintentional for } \\
\text { compromised patients }\end{array}$ & 2.0 \\
\hline $\begin{array}{l}\text { Altorki } \\
\text { et } \mathrm{al}^{20}\end{array}$ & 2016 & $\begin{array}{l}\text { Division of Thoracic } \\
\text { Surgery, Department of } \\
\text { Cardiothoracic Surgery, } \\
\text { New York Presbyterian } \\
\text { Hospital, Weill Cornell } \\
\text { Medical College, New } \\
\text { York, NY, USA }\end{array}$ & $2000-20 \mid 4$ & 129 & 160 & $\begin{array}{l}\text { Unintentional and intentional: } \\
\text { for smaller, pleural-based } \\
\text { tumors; we prefer WR, } \\
\text { poor performance status and } \\
\text { debilitating comorbidities }\end{array}$ & 3.0 \\
\hline
\end{tabular}


Table I (Continued)

\begin{tabular}{|c|c|c|c|c|c|c|c|}
\hline Study & Year & Institution & $\begin{array}{l}\text { Study } \\
\text { period }\end{array}$ & $\begin{array}{l}\text { Segmentectomy } \\
\text { (n) }\end{array}$ & $\begin{array}{l}\text { Wedge } \\
\text { resection (n) }\end{array}$ & $\begin{array}{l}\text { Reasons for sublobar } \\
\text { approach }\end{array}$ & $\begin{array}{l}\text { Tumor } \\
\text { size }(\mathrm{cm})\end{array}$ \\
\hline $\begin{array}{l}\text { Tsutani } \\
\text { et al }{ }^{21}\end{array}$ & 2014 & $\begin{array}{l}\text { Department of Surgical } \\
\text { Oncology, Research } \\
\text { Institute for Radiation } \\
\text { Biology and Medicine, } \\
\text { Hiroshima University, } \\
\text { Hiroshima, Japan }\end{array}$ & $2005-2010$ & 56 & 93 & Intentional for GGO & 3.0 \\
\hline $\begin{array}{l}\text { Tamura } \\
\text { et a }\left.\right|^{22}\end{array}$ & 2014 & $\begin{array}{l}\text { Department of General } \\
\text { and Cardiothoracic } \\
\text { Surgery, School of } \\
\text { Medicine, Kanazawa } \\
\text { University, Kanazawa, } \\
\text { Japan }\end{array}$ & 1996-2009 & 89 & 149 & $\begin{array}{l}\text { Unintentional for high-risk } \\
\text { status }\end{array}$ & 3.0 \\
\hline $\begin{array}{l}\text { Zhang } \\
\text { et } \mathrm{al}^{23}\end{array}$ & 2016 & $\begin{array}{l}\text { Department of Thoracic } \\
\text { Surgery, Fudan University } \\
\text { Shanghai Cancer Center, } \\
\text { Shanghai, China }\end{array}$ & $1998-2012$ & NR & NR & NR: invasive adenocarcinoma & 2.0 \\
\hline $\begin{array}{l}\text { Zhang } \\
\text { et } \mathrm{al}^{23}\end{array}$ & 2016 & $\begin{array}{l}\text { Department of Thoracic } \\
\text { Surgery, Fudan University } \\
\text { Shanghai Cancer Center, } \\
\text { Shanghai, China }\end{array}$ & $1998-2012$ & NR & NR & NR: squamous cell carcinoma & 2.0 \\
\hline $\begin{array}{l}\text { Zhang } \\
\text { et } \mathrm{al}^{23}\end{array}$ & 2016 & $\begin{array}{l}\text { Department of Thoracic } \\
\text { Surgery, Fudan University } \\
\text { Shanghai Cancer Center, } \\
\text { Shanghai, China }\end{array}$ & $1998-2012$ & 786 & 3,145 & NR: invasive adenocarcinoma & 3.0 \\
\hline $\begin{array}{l}\text { Zhang } \\
\text { et } \mathrm{al}^{23}\end{array}$ & 2016 & $\begin{array}{l}\text { Department of Thoracic } \\
\text { Surgery, Fudan University } \\
\text { Shanghai Cancer Center, } \\
\text { Shanghai, China }\end{array}$ & $1998-2012$ & 370 & 1,579 & NR: squamous cell carcinoma & 3.0 \\
\hline Dai et $\mathrm{a}^{24}$ & 2016 & $\begin{array}{l}\text { Shanghai Pulmonary } \\
\text { Hospital, Tongji } \\
\text { University School of } \\
\text { Medicine, Shanghai, China }\end{array}$ & $2000-2012$ & 160 & 821 & Intentional & 1.0 \\
\hline
\end{tabular}

Abbreviations: GGO, ground glass opacity; NR, not reported; WR, wedge resection.

Table 2 Component ratio of included studies

\begin{tabular}{|c|c|c|c|c|}
\hline \multirow[t]{2}{*}{ Study } & \multicolumn{2}{|c|}{ Age (mean), years } & \multicolumn{2}{|c|}{ Male gender, n (\%) } \\
\hline & $\overline{\mathbf{S}}$ & $\mathbf{W}$ & $\overline{\mathbf{S}}$ & $\mathbf{W}$ \\
\hline$\overline{O k a d a}$ et al ${ }^{7}$ & 63 & 63 & NR (54.8) & NR (54.8) \\
\hline Sugi et $\mathrm{al}^{8}$ & $61.6 \pm 9.4$ & $62.5 \pm 13.4$ & $19(30.6)$ & $13(38.2)$ \\
\hline Hamatake et al ${ }^{17}$ & $64.0(\mathrm{M})$ & $64.0(\mathrm{M})$ & $62(43.4)$ & $62(43.4)$ \\
\hline Sienel et al ${ }^{18}$ & $67 \pm 9$ & $63 \pm 8$ & NR (64) & NR $(8 I)$ \\
\hline Sienel et a $\left.\right|^{18}$ & $67 \pm 9$ & $63 \pm 8$ & NR (64) & NR (8I) \\
\hline Yamato et $\mathrm{al}^{19}$ & 65.2 & 65.2 & NR (50) & NR (50) \\
\hline Altorki et $\mathrm{a}^{20}$ & $71.0(\mathrm{M})$ & $74.0(M)$ & $53(43.4)$ & $68(42.5)$ \\
\hline Tsutani et $\mathrm{al}^{21}$ & 65 & 65 & $94(39.3)$ & $94(39.3)$ \\
\hline Tamura et $\mathrm{al}^{22}$ & 67 & 67.7 & $90(60.4)$ & $57(64.0)$ \\
\hline Zhang et $\mathrm{a}^{23}$ & 69 & 69.1 & $296(37.7)$ & $\mathrm{I}, 374(43.7)$ \\
\hline Zhang et $\mathrm{a}^{23}$ & 71.3 & 71.7 & $185(50)$ & $811(5 I .4)$ \\
\hline Zhang et $\mathrm{a}^{23}$ & 69 & 69.1 & $296(37.7)$ & $\mathrm{I}, 374(43.7)$ \\
\hline Zhang et $\mathrm{a}^{23}$ & 71.3 & 71.7 & I $85(50)$ & 811 (5I.4) \\
\hline Dai et $\mathrm{al}^{24}$ & $>65(62 \%)$ & $>65(65 \%)$ & $218(36)$ & $\mathrm{I}, 0 \mathrm{I7}(4 \mathrm{I})$ \\
\hline
\end{tabular}

Abbreviations: NR, number not reported; M, median \pm variance; $S$, patients who underwent segmentectomy; $W$, patients who underwent wedge resection. 


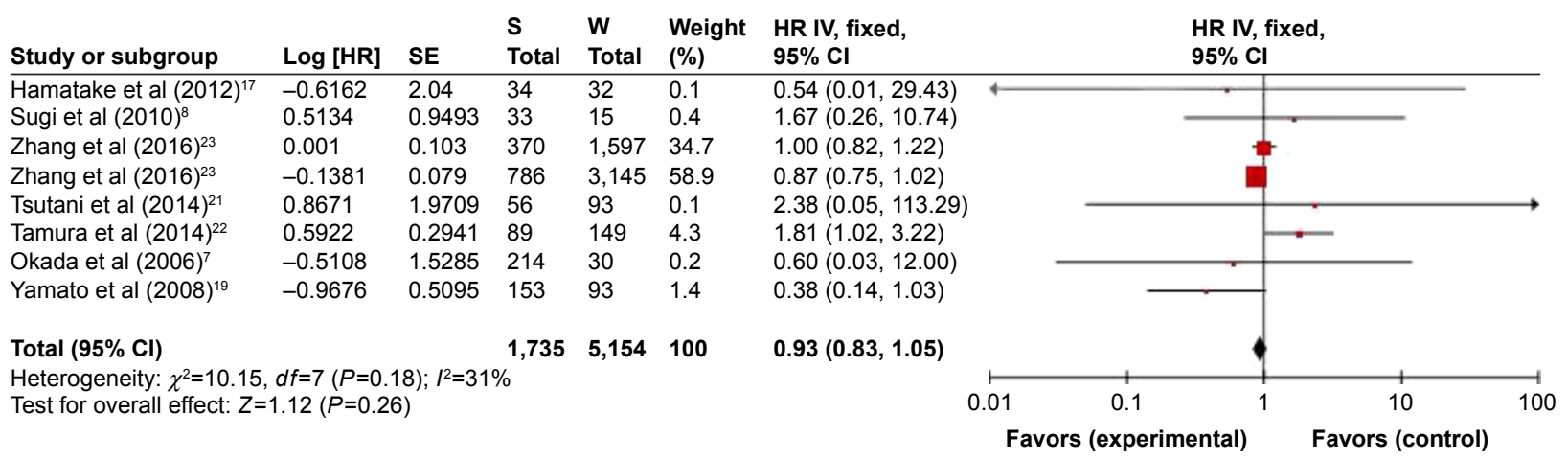

Figure 2 OS of segmentectomy versus wedge resection for stage IA NSCLC.

Abbreviations: OS, overall survival; NSCLC, non-small-cell lung cancer; HR, hazard ratio; IV, inverse variance; SE, standard error; Cl, confidence interval; S, patients who underwent segmentectomy; $\mathrm{W}$, patients who underwent wedge resection.

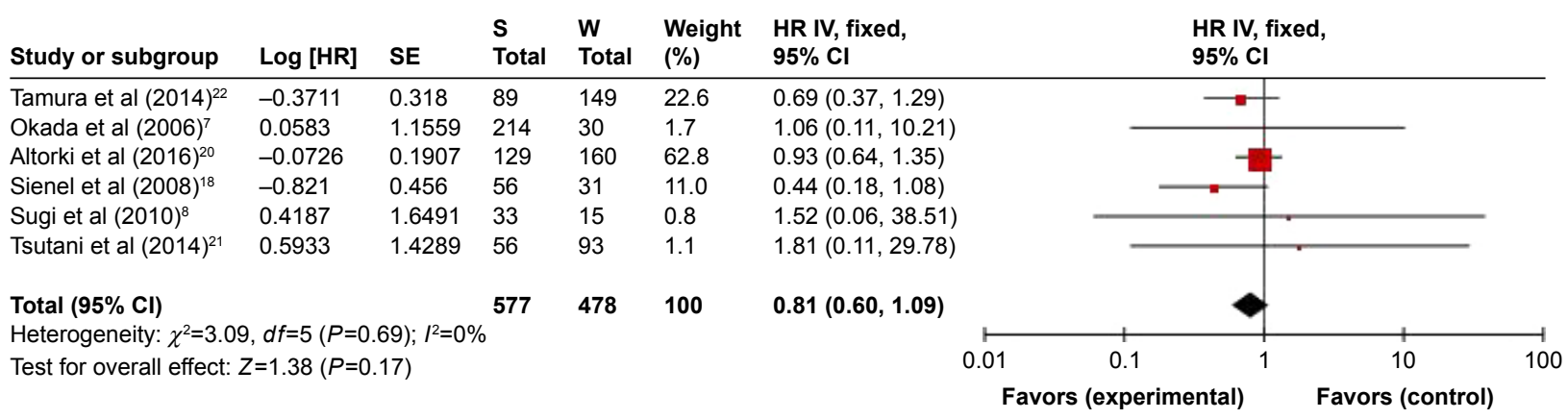

Figure 3 DFS of segmentectomy versus wedge resection for stage IA NSCLC.

Abbreviations: DFS, disease-free survival; NSCLC, non-small-cell lung cancer; HR, hazard ratio; IV, inverse variance; SE, standard error; Cl, confidence interval; S, patients who underwent segmentectomy; W, patients who underwent wedge resection.

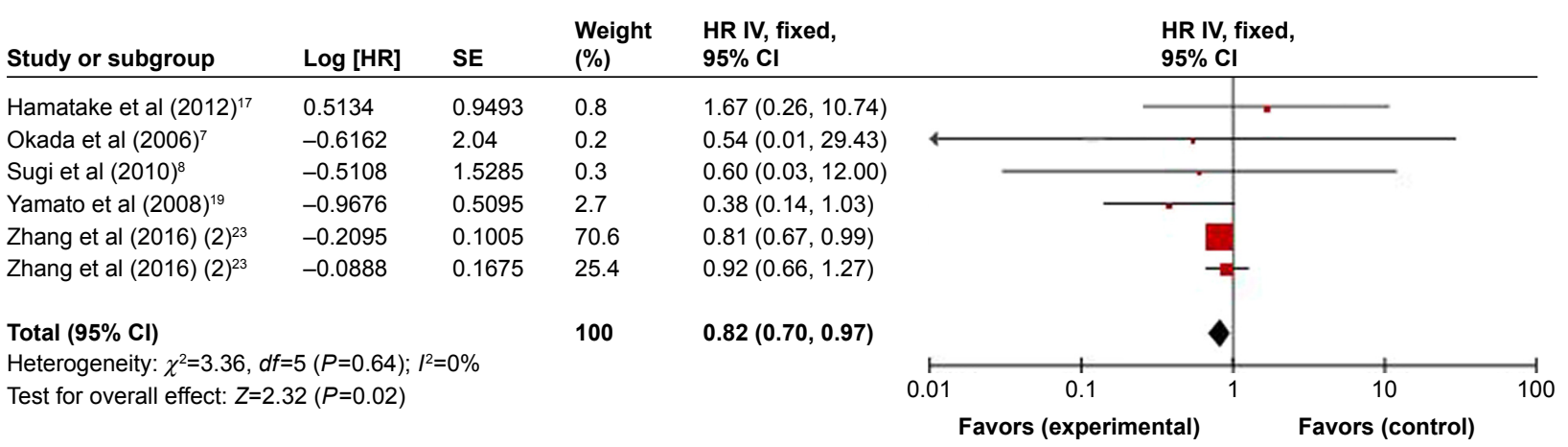

Figure 4 OS of segmentectomy versus wedge resection for NSCLC with tumor size $\leq 2 \mathrm{~cm}$.

Abbreviations: OS, overall survival; NSCLC, non-small-cell lung cancer; HR, hazard ratio; IV, inverse variance; SE, standard error; Cl, confidence interval.

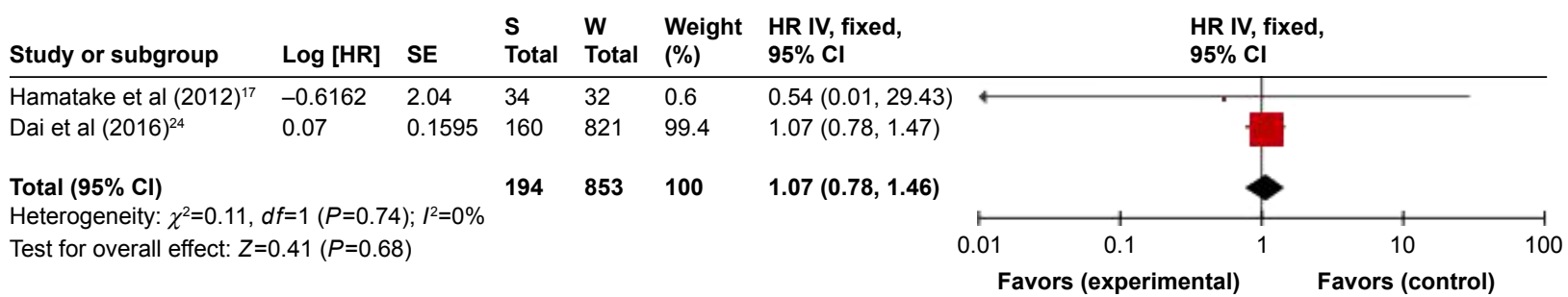

Figure $\mathbf{5}$ OS of segmentectomy versus wedge resection for NSCLC with tumor size $\leq \mathrm{I} \mathrm{cm}$.

Abbreviations: OS, overall survival; NSCLC, non-small-cell lung cancer; HR, hazard ratio; IV, inverse variance; SE, standard error; Cl, confidence interval; S, patients who underwent segmentectomy; $W$, patients who underwent wedge resection. 


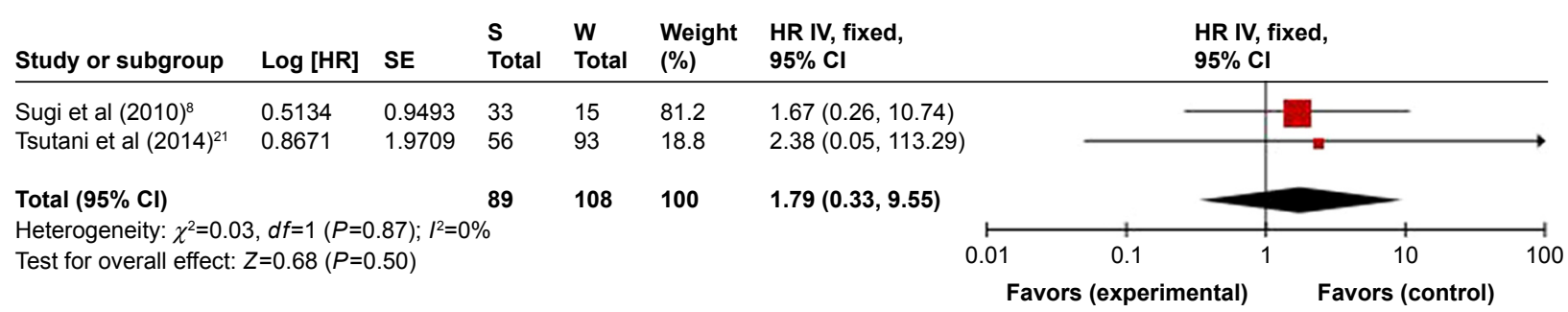

Figure 6 OS of segmentectomy versus wedge resection for GGO NSCLC.

Abbreviations: OS, overall survival; GGO, ground glass opacity; NSCLC, non-small-cell lung cancer; HR, hazard ratio; IV, inverse variance; SE, standard error; Cl, confidence interval; S, patients who underwent segmentectomy; W, patients who underwent wedge resection.

\section{Sensitivity analysis and publication bias}

The outcomes were similar whether fixed-effects models or random-effects models were used. A funnel plot estimating the precision of the trials (plots of the logarithm of the HR for efficacy against sample size) was examined for asymmetry to determine publication bias.

\section{Discussion}

Lobectomy has been considered as the standardized surgical approach of early stage NSCLC in the last few decades. Only the randomized clinical trial by the Lung Cancer Study Group $^{2}$ showed the superiority of lobectomy. However, 30\% of sublobar resection was wedge resection and not segmentectomy in this trial. Most studies supported lobectomy, without considering the factors affecting survival such as tumor size, differences in limited resections, the age of patients, patients combining with comorbidities and the type of lymph node dissection. The intentional sublobectomy can receive equivalent survival to lobectomy for early stage NSCLC..$^{9,15,16}$ Hence, the limited resection was considered the surgical method for the early stage NSCLC as far as the preservation of lung function was concerned. The study by Smith et $\mathrm{a}^{10}$ through the Surveillance, Epidemiology and End Results (SEER)Medicare registry indicated that segmentectomy should be the preferred technique for limited resection of patients with stage IA NSCLC. However, the subsequent Japanese studies demonstrated that only tumors up to $2 \mathrm{~cm}$ are indication for segmentectomy. In this study, for stage IA NSCLC, the HR of OS of 0.93 (95\% CI: $0.83-1.05, P=0.26$ ) and HR of DFS of 0.81 ( $95 \%$ CI: $0.60-1.09, P=0.17$ ) showed that segmentectomy was not superior to wedge resection. While for tumor size $\leq 2 \mathrm{~cm}$, it was in favor of segmentectomy for the better OS of combined HR of 0.82 (95\% CI: $0.70-0.97, P=0.02$; Figure 4). Moreover, the GGO of early stage NSCLC was detected by HRCT; combining the HR of OS of 1.79 ( $95 \%$ CI: $0.33-9.55, P=0.50)$ and HR of DFS of 1.68 (95\% CI: 0.20 13.94, $P=0.63$ ) demonstrated that wedge resection received the similar survival rate compared to segmentectomy. Since there were only two studies in this comparison and the ratio of GGO was the independent factor of OS and DFS, we could not draw a definite conclusion. In this study, there were three studies that underwent sublobar approach for patients with cardiopulmonary impairment. It was also the important factor leading to the heterogeneity between studies. Because of the highly selected patients according to the accurate criteria and all retrospective studies with no randomized controlled trial (RCT) test, the level of evidence was low. Because systematic lymph node resection for the early stage NSCLC is still controversial the, number of included literature was only 9 .

\section{Conclusion}

This meta-analysis suggests that segmentectomy compared with wedge resection may lead to better survival rate for tumor size $\leq 2 \mathrm{~cm}$ NSCLC. For tumor size $\leq 1 \mathrm{~cm}$ and GGO

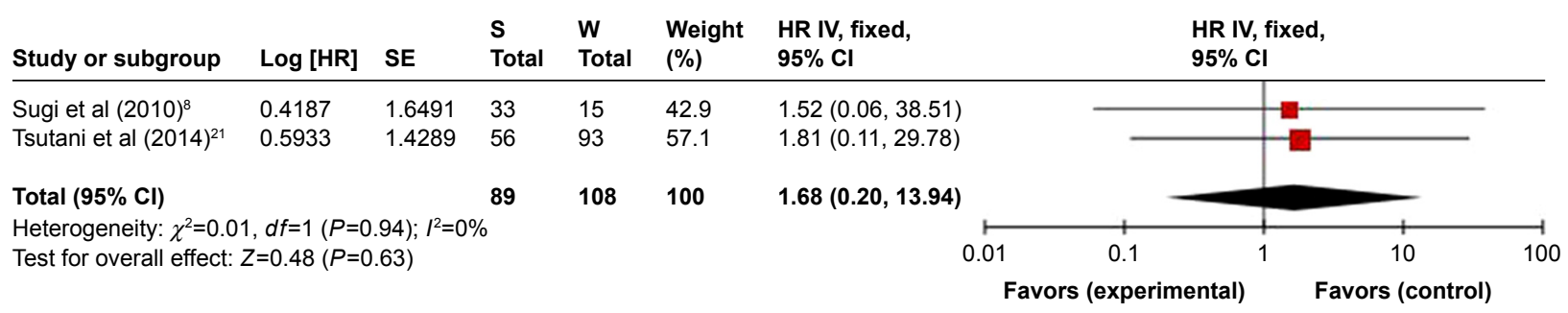

Figure 7 DFS of segmentectomy versus wedge resection for GGO NSCLC.

Abbreviations: DFS, disease-free survival; GGO, ground glass opacity; NSCLC, non-small-cell lung cancer; HR, hazard ratio; SE, standard error; IV, inverse variance; $\mathrm{Cl}$, confidence interval; S, patients who underwent segmentectomy; W, patients who underwent wedge resection. 
NSCLC, patients who received wedge resection achieved comparable survival to those who underwent segmentectomy. The results and conclusion should be confirmed by a large, randomized, prospective study (ACOSOG4032) and the Cancer and Lymphoma Group B (CALGB 140503).

\section{Disclosure}

The authors report no conflicts of interest in this work.

\section{References}

1. Aberle DR, Adams AM, Berg CD, et al. Reduced lung-cancer mortality with low-dose computed tomographic screening. N Engl J Med. 2011; 365(5):395-409.

2. Ginsberg RJ, Rubinstein LV. Lung Cancer Study Group: randomized trial of lobectomy versus limited resection for T1 N0 non-small cell lung cancer. Ann Thorac Surg. 1995;60(3):615-622, discussion 622-623.

3. Zhong C, Fang W, Mao T, Yao F, Chen W, Hu D. Comparison of thoracoscopic segmentectomy and thoracoscopic lobectomy for small-sized stage IA lung cancer. Ann Thorac Surg. 2012;94(2):362-367.

4. Wisnivesky JP, Henschke CI, Swanson S, et al. Limited resection for the treatment of patients with stage IA lung cancer. Ann Surg. 2010; 251(3):550-554.

5. Koike T, Yamato Y, Yoshiya K, Shimoyama T, Suzuki R. Intentional limited pulmonary resection for peripheral T1 N0 M0 small-sized lung cancer. J Thorac Cardiovasc Surg. 2003;125(4):924-928.

6. Watanabe T, Okada A, Imakiire T, et al. Intentional limited resection for small peripheral lung cancer based on intraoperative pathologic exploration. Jpn J Thorac Cardiovasc Surg. 2005;53:29-35.

7. Okada M, Koike T, Higashiyama M, Yamato Y, Kodama K, Tsubota N. Radical sublobar resection for small-sized non-small cell lung cancer: a multicenter study. J Thorac Cardiovasc Surg. 2006;132(4):769-775.

8. Sugi K, Kobayashi S, Sudou M, Sakano H, Matsuda E, Okabe K. Longterm prognosis of video-assisted limited surgery for early lung cancer. Eur J Cardiothorac Surg. 2010;37(2):456-460.

9. Tsutani Y, Miyata Y, Nakayama H, et al. Oncologic outcomes of segmentectomy compared with lobectomy for clinical stage IA lung adenocarcinoma: propensity score-matched analysis in a multicenter study. J Thorac Cardiovasc Surg. 2013;146(2):358-364.

10. Smith CB, Swanson SJ, Mhango G, Wisnivesky JP. Survival after segmentectomy and wedge resection in stage I non-small-cell lung cancer. J Thorac Oncol. 2013;8(1):73-78.

11. Koike T, Koike T, Yoshiya K, Tsuchida M, Toyabe S. Risk factor analysis of locoregional recurrence after sublobar resection in patients with clinical stage IA non-small cell lung cancer. J Thorac Cardiovasc Surg. 2013;146(2):372-378.
12. Parmar MK, Torri V, Stewart L. Extracting summary statistics to perform meta-analyses of the published literature for survival endpoints. Stat Med. 1998;17(24):2815-2834.

13. Tierney JF, Stewart LA, Ghersi D, Burdett S, Sydes MR. Practical methods for incorporating summary time-to-event data into metaanalysis. Trials. 2007;8:16.

14. Egger M, Smith GD, Schneider M, Minder C. Bias in meta-analysis detected by a simple, graphical test. BMJ. 1997;315(7109):629-634.

15. Zhao X, Qian L, Luo Q, et al. Segmentectomy as a safe and equally effective surgical option under complete video-assisted thoracic surgery for patients of stage I non-small cell lung cancer. J Cardiothorac Surg. 2013;8:116.

16. Shapiro M, Weiser TS, Wisnivesky JP, Chin C, Arustamyan M, Swanson SJ. Thoracoscopic segmentectomy compares favorably with thoracoscopic lobectomy for patients with small stage I lung cancer. J Thorac Cardiovasc Surg. 2009;137(6):1388-1393.

17. Hamatake D, Yoshida Y, Miyahara S, Yamashita S, Shiraishi T, Iwasaki A. Surgical outcomes of lung cancer measuring less than $1 \mathrm{~cm}$ in diameter. Interact Cardiovasc Thorac Surg. 2012;15(5):854-858.

18. Sienel W, Dango S, Kirschbaum A, et al. Sublobar resections in stage Ia non-small cell lung cancer: segmentectomies result in significantly better cancer-related survival than wedge resections. Eur J Cardiothorac Surg. 2008;33(4):728-734.

19. Yamato Y, Koike T, Yoshiya K, Shinohara H, Toyabe S. Results of surgical treatment for small (2 $\mathrm{cm}$ or under) adenocarcinomas of the lung. Surg Today. 2008;38(2):109-114.

20. Altorki NK, Kamel MK, Narula N, et al. Anatomical segmentectomy and wedge resections are associated with comparable outcomes for patients with small cT1N0 non-small cell lung cancer. J Thorac Oncol. 2016;11(11):1984-1992.

21. Tsutani Y, Miyata Y, Nakayama H, et al. Appropriate sublobar resection choice for ground glass opacity-dominant clinical stage IA lung adenocarcinoma wedge resection or segmentectomy. Chest. 2014; 145(1):66-71.

22. Tamura M, Matsumoto I, Takata M, et al. Sublobar resections in stage IA non-small cell lung cancer: segmentectomy versus wedge resection. Ind J Thorac Cardiovasc Surg. 2014;30(4):264-271.

23. Zhang Y, Sun Y, Chen H. A propensity score matching analysis of survival following segmentectomy or wedge resection in early-stage lung invasive adenocarcinoma or squamous cell carcinoma. Oncotarget. 2016;12(7):13880-13885

24. Dai C, Shen J, Ren Y, et al. Choice of surgical procedure for patients with non-small-cell lung cancer $\leq 1 \mathrm{~cm}$ or $>1$ to $2 \mathrm{~cm}$ among lobectomy, segmentectomy, and wedge resection: a population-based study. J Clin Oncol. 2016;34(26):3175-3182.
OncoTargets and Therapy

\section{Publish your work in this journal}

OncoTargets and Therapy is an international, peer-reviewed, open access journal focusing on the pathological basis of all cancers, potential targets for therapy and treatment protocols employed to improve the management of cancer patients. The journal also focuses on the impact of management programs and new therapeutic agents and protocols on

\section{Dovepress}

patient perspectives such as quality of life, adherence and satisfaction. The manuscript management system is completely online and includes a very quick and fair peer-review system, which is all easy to use. Visit http://www.dovepress.com/testimonials.php to read real quotes from published authors. 